\title{
CURRENT CASELAW DISCREPANCIES IN THE PROTECTION OF NATIONAL SYMBOLS AND STATE REPRESENTATIVES BETWEEN THE EUROPEAN COURT OF HUMAN RIGHTS AND SPANISH COURTS: A VICIOUS CIRCLE.
}

\author{
ANDRÉS GASCÓN CUENCA*
}

\begin{abstract}
Despite the general consensus about freedom of expression being a basic fundamental right on every democratic society, the debate about its boundaries has never found such a pacific agreement. Thus, the Spanish Penal Code has several articles that punish its abuse that are highly contested, like articles 490.3 and 543 that penalize the offenses directed towards national symbols or State representatives. This being so, this article examines the controversy generated by the application of this articles through the analysis of two judgements issued by the European Court of Human Rights against Spain, and a third one issued by the Spanish Constitutional Court that could follow the same path. This work will be done to describe the clash that exists between the caselaw of these two jurisdictions, in order to critically analyze the approach Spanish courts have to behaviors that criticize national symbols and state representatives.
\end{abstract}

Keywords: Freedom of expression; limitation; offense; national symbols; state representatives; ECtHR caselaw.

Summary: 1. Introduction. 2. Case of Otegi Mondragón v. Spain. 2.1. Proceedings followed before the Spanish courts. 2.2. The case before the ECtHR. 2.3. Discrepancies between the two jurisdictions. 3. CASE OF Stern Taulats and Roura Capellera v. Spain. 3.1. The case before the Spanish courts. 3.2. The case before the ECtHR. 3.3. An expected result. 4. SCC CASE 190/2020 (flag SCORning CASE). 5. Some COnCLusions.

\section{INTRODUCTION}

The identification of the limits of the right to freedom of expression is a debate innate to the history of our democracies. Since the French Declaration of the Rights of the Man and the Citizen of 1789, an important number of international treaties and national constitutions protect this right establishing that, although it must be considered as fundamental to every democracy, it might be subjected to some legal restrictions. Currently, the debate about its boundaries is at the center of the Spanish political discussion, since the great attention that the limitations imposed by the Spanish Penal Code (PC) have in the public debate about social concerning issues like: migration, xenophobia, LGTBIQ+ rights, violence against women, monarchy, among others.

Within this vast landscape, this piece of research will evaluate how the Spanish judicial system is receiving the standards set by the European Court of Human Rights

\footnotetext{
*University of Valencia, Human Rights Institute, Andres.gascon@uv.es.
} 
(ECtHR) when dealing with cases related to freedom of expression and offenses to national symbols and state representatives. ${ }^{1}$ To do so, on one hand, we will analyze the only two cases followed against Spain before the ECtHR regarding this matter (Otegi Mondragón v. Spain [2011], and Stern Taulats and Roura Capellera v. Spain [2018]). In both of them the ECtHR determined the violation of the article 10 of the ECHR because Spain failed to prove that the interference applied was necessary on a democratic society. On the other hand, and despite these two judgements, the Spanish Constitutional Court (SCC) in a 2020 decision (STC 190/2020 of December 15 th, 2020 ), continued ignoring the rationale used by the ECtHR when understanding this type of cases. This may lead to another judgement against Spain, on a very sensitive area like the protection of freedom of expression in a democratic rule of law state.

Therefore, the scope of this article is threefold. Firstly, we will identify the standards used by the ECtHR in the two abovementioned cases. Secondly, the same analysis will be done with SCC judgement. And lastly, both results will be compared and critically analyzed by constructing some conclusions that suggest new ways of addressing future cases related to offences to national symbols and state representatives.

\section{Case of Otegi Mondragón v. Spain. ${ }^{2}$}

This case was followed against Arnaldo Otegi Mondragon, a well-known member of the Basque independency movement and of the terrorist organization ETA. According to the proven facts at the national level of the process, Otegi Mondragon was the spokesperson of Sozialista Abertzaleak, a parliamentary group with political representation in the Basque Country Parliament. On February $21^{\text {st }}, 2003$, the premises of the newspaper Euskaldunon Egunkaria were searched and closed following an investigation leaded by the Audiencia Nacional, regarding the connections between this newspaper and ETA. On February $26^{\text {th }}, 2003$, the president of the Basque Country received the King of Spain at the opening of a power plant station. As a response to the visit, Otegi Mondragon as spokesperson of Sozialista Abertzaleak, organized a press conference where he referred to the King as "the Commander-in-Chief of the Spanish army, in other words, the person who is in charge of the torturers, who defends torture and imposes his monarchical regime to our people through torture and violence"3 (in reference to an alleged accusation of torture committed by members of the Civil Guard [CG] to the Euskaldunon Egunkaria detainees).

\subsection{Proceedings followed before the Spanish courts.}

The public prosecutor's office lodged a criminal complaint against Otegi Mondragon following the article 490.3 of the PC, that states "whoever slanders or insults the King or

\footnotetext{
${ }^{1}$ Articles 490.3 and 543 of the Spanish Penal Code. A relevant comparison of these type of crimes in different countries is done by Bilbao Ubillos 2021.

${ }^{2}$ ECtHR judgment Otegi Mondragón v. Spain Application (no. 2034/07).

${ }^{3}$ Basque Country Superior Court Judgement1206/2005, March 18 ${ }^{\text {th }}$, 2005. ECLI: ES:TSJPV:2005:1206
} 
Queen, any of their ascendants or descendants, the consort Queen or the Queen's consort, the Regent or any member of the Regency, or the Prince or Princess of Asturias, in the exercise of their functions or because of them, will be punished with a prison sentence from six months to two years if the slander or insult were serious, and with a fine from six to twelve months if they are not"4. According to the opinion of the public prosecutor, Otegi's remarks were "a serious insult" to the King.

Because of Otegi Mondragon was a MP at the Basque Country Parliament, the case was firstly followed by the High Court of the Basque Country (Soto García 2012). The strategy of the defense followed two pathways. On one hand, they asserted that his remarks were directed towards the King as supreme commander of the Spanish armed forces, meaning that Otegi Mondragon statements referred to the political reality of the King's life. On the other hand, they argued that regarding his comments towards the Civil Guard torturing the detained members of Euskaldunon Egunkaria, there was an ongoing investigation followed by the Courts in Madrid, and that numerous public figures had commented on this subject. All in all, Otegi Mondragon's lawyers pointed out that he was a politician exercising his right to freedom of expression by criticizing a situation that, according to him, was an extreme infringement of the fundamental rights of Euskaldunon Egunkaria detainees.

The High Court of the Basque Country found Otegi Mondragon not guilty of an offense of the article 490.3 PC. In its decision ${ }^{6}$, the judges holistically analyzed the situation where the statements were made, and the political position of the person who made them. This is important because the ECtHR caselaw states the obligation of doing this task in the cases dealing with freedom of expression in order to evaluate if the interference on this right follow the standard of necessary in a democratic society (Gascón Cuenca 2016, pp. 53-65). The judges of the High Court in their reasoning argued that the statements were made in public by a MP in a press conference with an institutional setting. Them were directed towards the Head of State, not in regards to his private life, but as the commander-in-chief of the Civil Guard, a police body under investigation because an allegation of torture. Thus, the High Court, even though recognizes that the statements were highly offensive, establishes that they must be protected by the right to freedom of expression as they were made by a politician to a political power of the state following an issue of public interest.

However, the public prosecutor lodge an appeal before the Supreme Court (SC). According to his opinion, the adequate interpretation of the article 490.3 PC makes impossible to differentiate between the private and public spheres of dignity of the King,

\footnotetext{
${ }^{4}$ Author's translation. Original text: 490.3 PC: El que calumniare o injuriare al Rey o Reina a cualquiera de sus ascendientes o descendientes, a la Reina consorte o al consorte de la Reina, al Regente o a algún miembro de la Regencia, o al Príncipe o Princesa de Asturias, en el ejercicio de sus funciones o con motivo u ocasión de éstas, será castigado con la pena de prisión de seis meses a dos años si la calumnia o injuria fueran graves, y con la de multa de seis a doce meses si no lo son.

${ }^{5}$ Basque Country Superior Court Judgement1206/2005, March 18 $8^{\text {th }}, 2005$. ECLI: ES:TSJPV:2005:1206

${ }^{6}$ Basque Country Superior Court Judgement1206/2005, March 18 ${ }^{\text {th }}, 2005$. ECLI: ES:TSJPV:2005:1206
} 
as its scope is to protect the Crown as an institution that is a symbol of the unity of the State. Therefore, the article 490.3 PC not only protects the King as a private person but also when performing his official duties. The SC followed these arguments and sentenced Otegi Mondragon to one-year imprisonment, because his statement exceeded the criticism protected by the right to freedom of expression. ${ }^{7}$

Unfortunately, SC in its analysis fails to evaluate the case from its holistic perspective. The arguments developed by this court only focus in the right to honor of the King, disregarding any link between the statements, the public debate, and the special protection the right to freedom of expression has in this field (Rodríguez Montañés 2013, p. 621). The SC is unsuccessful in recognizing the standards set by the caselaw of the ECtHR and the Human Rights Council when understanding cases that deal with the protection of fundamental or human rights, as the SC only constructs its arguments focusing on the article $490.3 \mathrm{PC}^{8}$, and not confronting it with other superior rights and values that this article might curtail.

Otegi Mondragon lawyer's lodged and amparo appeal ${ }^{9}$ before the Spanish Constitutional Court (SCC). However, this appeal was dismissed because the $\mathrm{SCC}^{10}$ followed the reasoning of the SC, validating their arguments and assessing that the case lacked constitutional relevance. ${ }^{11}$ The SCC stated that the right to freedom of expression is limited when the evaluated speech contains opprobrious statements that are completely unnecessary to communicate the intended ideas. ${ }^{12}$ Moreover, this right does not constitutionally protect a right to insult. ${ }^{13}$ Thus, the SCC decided that Otegi Mondragon's statements declaring that the King was the person "in charge of torturers" and that "imposes his monarchical regime in our people through torture and violence" were shameful and infamous for any person, even public figures. These statements contained unproven criminal charges that could not be protected by the right to freedom

\footnotetext{
${ }^{7}$ According to Sánchez de Diego Fernández de la Riva (2011, pp. 19-20), Otegi's statements qualify as hate speech. However, as I will argue, Otegi's behavior cannot be qualified as hate speech as it was not directed towards one of the groups traditionally protected from this kind of speech.

${ }^{8}$ As pointed out by Gómez Corona (2011, p. 731), the SC when justifying its sentencing, uses "circular arguments", meaning that the court only justification to exclude the statements from the protection granted by the Spanish Constitution is that they offend the Head-of-State, so that they are excluded.

${ }^{9}$ The amparo is the last judicial appeal that exist in the Spanish legal system, only available when the case refers to a matter specifically protected in the Constitution. It is lodged before the Constitutional Court.

${ }^{10}$ SCC, auto 213/2006, de 3 de julio. ECLI:ES:TC:2006:213A

${ }^{11}$ SCC, auto 213/2006, de 3 de julio, antecedent 5. ECLI:ES:TC:2006:213A. In this case, the lack of constitutional relevance is highly debatable as it refers to a case where the right to freedom of expression is being curtailed in the area of public debate. The SCC cannot disregard its duties of surveillance and protection of fundamental rights, especially in highly debatable cases that are placed at the grey area of the protection of a right. By dismissing the case without evaluating it, the SCC is creating an unacceptable slippery slope tendency against a fundamental and human right. Moreover, it seemed that the SCC preferred not to issue a judgment contradicting the SC instead of applying the standards set by the ECtHR for these matters (Gómez Corona 2011, pp. 731-732; Rodríguez Montañés 2013, p. 625).

${ }^{12}$ SCC judgment $107 / 188$, June $8^{\text {th }}$. ECLI:ES:TC:1988:107

${ }^{13}$ SCC judgment 6/2000, January $18^{\text {th }}$. ECLI:ES:TC:2000:6
} 
of expression. ${ }^{14}$ The SCC recognizes that in a democratic state that protects freedom of thought and expression the figure of the King cannot be shield from any form of criticism, but this cannot amount the imputation of criminal charges as the King, according to the Spanish constitution, is inviolable.

Once again, the evaluation of the case made by the SCC not only lacks a holistic approach, but also makes a strange interpretation of the King's inviolability. Firstly, it is not taken into consideration that the speech was performed by a member of the Basque Parliament, referring to the King as the commander-in-chief of a "group of torturers" (the Civil Guard), a situation that was under judicial investigation by a court in Madrid (although the case was dismissed later on). Secondly, SCC makes an inadequate interpretation of the inviolability set by the Constitution to the figure of the King. The inviolability protection means that the King is protected from any prosecution before the courts. However, Otegi Mondragon was not trying to initiate a proceeding against him, he was referring to him as the Head of State and responsible of the Spanish armed forces. Thus, there is no link between the animus to which the inviolability protection was created and the limitation of the right to freedom of expression.

\subsection{The case before the ECtHR.}

The ECtHR has developed a threefold examination process when evaluating a case that imposes a limitation on the article 10 ECHR. These standards are: 1 . Is the interference prescribed by the law? 2. Does it pursue a legitimate aim? And 3. Is the adopted measure necessary in a democratic society? In this case, the first two are met, as the case was followed according to an article of the PC in order to protect the reputation and rights of the King. However, the evaluation of the third standard needs a deeper analysis.

The ECtHR constantly repeats on its caselaw that the right to freedom of expression not only protects information or ideas that are favorably received or regarded as inoffensive, but also the ones that may offend, shock or disturb the society. This is based on the principles of pluralism, tolerance, and broadmindedness located at the backbones of every democratic state. So that, in order to assess if the specific interference is necessary in a democratic society, the ECtHR evaluates the possible existence of a social pressing need to justify it. That is, if the reasons adduced by the national authorities to justify the limitation on the right are relevant enough to consider them proportionate to protect the legitimate aim alleged. ${ }^{15}$

The ECtHR proceeded with a holistic evaluation of the case, appraising three areas: firstly, the kind of speech given by Otegi Mondragón; secondly, King's public figure; and lastly, the prison sentence.

\footnotetext{
${ }^{14}$ Previous Constitutional Court decisions already decided this way, by excluding from the protection of the fundamental right to freedom of expression statements directed towards politicians containing unproven criminal charges, as the affect their dignity. SCC judgment 190/1995, November $16^{\text {th }}$. ECLI:ES:TC:1992:190 ${ }^{15}$ The ECtHR recall here the case Mamère vs. France, 7 November 2006, para. 20. The ECtHR affirms that the margin of appreciation for the authorities to evaluate the social pressing need is quite narrow in this kind of cases.
} 
With regard to the kind of speech given by Otegi Mondragón, the ECtHR has well established on its caselaw that freedom of expression is paramount in the area of political speech or debate. The discussion of public interest matters is fundamental for every democratic society, especially when the speech is given by a MP or other elected representative (Soto García 2012, p. 585). Otegi Mondragón was participating on a press conference held a couple of days after the arrest of the manager of the Euskaldon Egunkaria newspaper. The allegations of torture and ill-treatments were already under investigation by another court. Therefore, the ECtHR concludes that "there is a sufficiently strong link between the applicant's remarks and the allegations of ill-treatments made by the editorin-chief"16 of the newspaper.

Concerning King's public figure, the ECtHR has also determined on its caselaw that the level of criticism that a politician might receive and tolerate is higher than the one directed towards individuals. Even though the King occupies a neutral position in the Spanish political arena, this does not mean that he is abstracted from any form of criticism when performing his official duties. Otegi's statements were not directed towards his private life, so they could not affect his personal right to honor. Thus, the extreme criticism showed by Otegi's statements could not attack the dignity of the King as an individual, nor the way in which he performed his public duties (Rodríguez Montañés 2013, p. 631), because the remarks referred to him as commander-in-chief of the Civil Guard, without connecting him with any specific criminal offence. ${ }^{17}$

In relation to this issue, it is important to call into question the so call neutrality of the figure of the King of Spain. According to the article 56 Spanish Constitution (SC) the King is the Head of State, a symbol of the Spanish unity, and arbitrates and moderates the regular institutions' functioning. The Spanish unity rely, among others, on the values protected by the Spanish Constitution, namely: freedom, justice, equality and political pluralism. So, one of the uppermost duties of the King is to defend those values. However, important cases of corruption and undue influence linked with the Royal Family are now catching the attention of the news. The current King did not firmly condemn these actions nor referred to them as incompatible with the social and democratic rule of law state established by the SC. Therefore, it is essential for the construction of an open and democratic debate not to accept the limitations on the right to freedom of expression expressed by the Spanish courts, as it might introduce a slippery slope (Cuerda Arnau 2007, pp. 40-43) tendency to sanction any statement or news that examines the behaviors of the Royal Family or the King as Head-of-State.

As for the prison sentence, the ECtHR has well ascertained in his caselaw that depriving someone from his/her liberty in cases connected to political speech is compatible with article 10 ECHR only in exceptional circumstances, where other fundamental rights have been seriously impaired, to avoid chilling effects. ${ }^{18}$ This standard is not meet in this case.

\footnotetext{
${ }^{16}$ ECtHR judgment Otegi Mondragón v. Spain, para 55.

${ }^{17}$ ECtHR judgment Otegi Mondragón v. Spain, para. 55.

${ }^{18}$ ECtHR judgment Otegi Mondragón v. Spain, para 59-60; Martín Herrera 2018, pp. 57-61.
} 
On the whole, the ECtHR decided that Otegi's right to freedom of expression was violated, as the justifications alleged by Spain were not sufficient to demonstrate that the interference was necessary in a democratic society ${ }^{19}$, as the result of the judgement was disproportionated in relation to the legitime aim pursued (Rodríguez Montañés 2013, pp. 632-633).

\subsection{Discrepancies between the two jurisdictions}

This case is a clear example of the existing discrepancies between Spanish courts and the ECtHR when evaluating cases related to freedom of expression. Firstly, the SC and SCC found Otegi's assertions completely unnecessary and offensive to defend his ideas. ${ }^{20}$ This argument places the reasoning of their decision in a slippery slope, because content-related limitations, as expressed in this judgment, are excessively vague. ${ }^{21}$ Using undetermined arguments to limit fundamental rights makes impossible to individuals to adapt their behaviors for not committing a crime. Secondly, meanwhile Spanish courts have no problem with the special protection provided by the PC to the King $^{22}$, the ECtHR affirms that it goes against the preservation of a wide-open public debate, so it is contrary to the article 10 ECHR. As stated before, Spanish courts did not do a holistic analysis of the case, so they missed important factors for doing a proportionate evaluation. Lastly, the alleged position of neutrality and inviolability of the King, as a justification for the sentence against Otegi Mondragon is weak. The role public figures have in societies is always debatable, even in a harshly way. This first sentence against Spain should have made jurisdictional institutions reflect about their position regarding these matters (Gómez Corona 2011, p.741; Rodríguez Montañés 2013, p. 639). ${ }^{23}$ However, as we will show in the following sections, more cases against Spain were to come.

\section{Case of Stern Taulats and Roura Capellera v. Spain. ${ }^{24}$}

This case was followed against Jaume Roura Capellera and Enric Stern Taulats as responsible of burning a portrait of the Kings of Spain. The proven facts took place in Girona on September 13 $3^{\text {th }}$, 2007, on the occasion of a visit of the Kings of Spain to this city. On that day, it was organized a demonstration that had as motto "300 years of

\footnotetext{
${ }^{19}$ ECtHR judgment Otegi Mondragón v. Spain, para. 61.

${ }^{20}$ Supporting this vision: Soto García 2012, p. 589; Rodríguez Montañés 2013, p. 637.

${ }^{21}$ Vague limitations that might result in disproportionated prison sentences. Llabrés Fuster 2015a, p. 96.

${ }^{22}$ This agreement about the regulation established by the PC was show before in a case where the Audiencia Nacional ordered the seizure of the publication El Jueves, as it had in their cover a caricature of the Kings of Spain having sex. Gimbernat Ordeig, 2007. There are more cases related to the protection of the honor of the former King of Spain (Juan Carlos I), and the difficulty to separate between the public and the private spheres. Ramos does an important work collecting some of the most famous front pages that brought some journalist before the courts. Ramos 2007, pp. 151-186.

${ }^{23}$ Against this position: Serrano Maíllo 2011, p. 595.

${ }^{24}$ ECtHR judgment Stern Taurlas et Roura Capellera c. Espagne, 16 june 2018 (applications no. 51168/15b $\& 51186 / 15)$.
} 
Bourbons, 300 years fighting against the Spanish occupation". ${ }^{25}$ Once the demonstration finished, it was followed by a concentration on the Wine Square where Roura and Stern, wearing baklavas, placed a big upside-down picture of the Kings of Spain, sprayed it with an inflammable liquid, and set it on fire with a torch.

\subsection{The case before the Spanish courts}

This case was firstly heard before the Central Penal Court of the Audiencia Nacional (CPCAN). According to the article 490.3 PC, the CPCAN found the suspects guilty of a crime of defamation against the Spanish Crown, convicting them to 15 months in prison (the jail time was after replaced for a fine of $2.700 €$ ). On its reasoning, the CPCAN affirmed the behavior of Stern and Roura had no other intention but to slander and scorn the Kings by placing an upside-down picture of them with the intention of setting it on flames. Moreover, the CPCAN declares that in a democratic rule-of-law state, citizens' fundamental rights are fully protected, so no one has a need to cover oneself to exercise them.

Roura and Stern's lawyer lodged an appeal before the Criminal Plenary Chamber of the Audiencia Nacional (CPlenCAN), that was rejected. Following the arguments used by the CPCAN on its decision, the CPlenCAN confirmed that by covering their face, placing an upside-down picture of the Kings and lighting it, Roura and Stern's actions cannot be protected by the right to freedom of expression as it represented a "witches' coven or an inquisitorial judgement" 26 against the Head-of-State. The CPlenCAN affirms that this action was completely unnecessary to defend the political opinion of the people gathered in the square, as it was formally slanderous, so it harmed the right to honor of the Crown.

As we can see, both the CPCAN and the CPlenCAN are unsuccessful in evaluating all the circumstances of the event. Even though the two decisions mentioned that the demonstration took place on the occasion of the visit of the King to Girona, they failed to acknowledge that the picture burning was the final act of a rally in favor of the independence of Catalonia. It is well known that a section of the people that defend this political position see Spain and its institutions as an oppressive occupying force, that prevents them from being an independent and republican nation. Although extremely harsh, socking and disturbing, this act followed no other end than to present this idea that has been (and will continue being) widely discussed on the political sphere. Moreover, the assertion that citizens do not need to cover themselves to exercise their legitimate rights lacks any legal reasoning, as it presupposes that by covering oneself up, no right can be lawfully practiced. No law prohibits wearing a baklava on public streets, and to wear it does not legally invalidate the exercise of a right per se (specially nowadays, with the obligation of wearing face masks that also make it difficult to identify individuals). When

\footnotetext{
${ }^{25}$ Author's translation. Original text: “300 años de Borbones, 300 años combatiendo la ocupación española”. SCC judgment 177/2015, 22 of June. ECLI:ES:TC:2015:177

${ }^{26}$ SCC judgment 177/2015, 22 of June. ECLI:ES:TC:2015:177
} 
this is done to remain anonymous when committing a crime, it might be considered as a factor to aggravate the sentence. Regarding this case, the picture burning was done in the middle of a crowded square, with press recording it. Even though Roura and Stern were covering their faces, their identification should not have been a difficult task for the police. Therefore, the assertion of the CPCAN and CPlenCAN discussed here is not acceptable as it is based on a prejudice that does not find any legal support.

Following the proceedings, Roura and Stern's lawyer lodged a recurso de amparo before de SCC. In its decision 177/2015 ${ }^{27}$, the SCC upheld the sentence imposed by the CPCAN, basing its judgement in the following fundamental items:

1. Firstly, the SCC recalls the central role that the right to freedom of expression has in a free a democratic society, as it is basic in the formation of the public's opinion. Following this idea (that we also find in the ECtHR case-law), the SCC affirms that this right has to be widely granted, protecting not only the opinions that are peacefully admitted by the society, but also the ones that bother, perturb, upset or shock. By defending a freedom of expression that covers a vast range of opinions, the SCC confirms that Spain is a nonmilitant democracy. ${ }^{28}$ However, as in the case of Otegi Mondragon, the SCC excludes form the protection granted by the SC expressions that are undoubtfully slanderous and completely unnecessary for the exposition of the ideas that are being defended. At this point, the SCC brings into the judgement the concept of hate speech. Besides the problems that this represents from the procedural point of view ${ }^{29}$, the definition of hate speech used by SCC not only ignores the one issued by the Council of Europe in its Recommendation $\mathrm{R}$ (97) $20^{30}$, but also the interpretation that the ECtHR does about this concept on its extensive case-law regarding this matter (Presno Linera, 2018, pp. 544-545). The SCC sustains that setting on fire the portrait implies per se hate speech as it entails "exclusion and hate". ${ }^{31}$ Moreover, the SCC extends the conception of hate $\operatorname{speech}^{32}$, ignoring that this

\footnotetext{
${ }^{27}$ SCC judgment 177/2015, from July 22 ${ }^{\text {nd }}, 2015$. ECLI:ES:TC:2015:177. Three judges expressed dissenting opinions.

${ }^{28}$ This is particularly important, because the subsequent SCC arguments will contradict this.

${ }^{29}$ As pointed out by Judge Asua Batarrita on her dissenting opinion, this was not discussed in the previous judgements, so it implies introducing new elements as proven facts in the constitutional revision. This might contradict the limitations imposed by the article 44 of the Organic Law $2 / 1979$, October $3^{\text {rd }}$, that regulates the SCC.

${ }^{30}$ The Recommendation No. R (97) 20 defines in its appendix the term hate speech as covering all forms of expression which spread, incite, promote or justify racial hatred, xenophobia, anti-Semitism or other forms of hatred based on intolerance, including: intolerance expressed by aggressive nationalism and ethnocentrism, discrimination and hostility against minorities, migrants and people of immigrant origin. Accessible at: https://rm.coe.int/1680505d5b

${ }^{31}$ SCC judgment 177/2015, from July 22nd 2015 , para. 4.

${ }^{32}$ As pointed out by Martín Herrera (2018, pp. 66-68), this contradictory use of the hate speech concept might be done on purpose in order to prevent a new sentence against Spain by the ECtHR, by identifying the behavior being judged with one of the limitations of the right to freedom of expression declared by the ECtHR. Supporting this position Bilbao Ubillos 2018, pp. 16-20. As pointed out by Laurenzo Copello (2019, pp. 455-456), the expansion of the concept of hate speech alters its roots by manipulating its essential features. Following this idea, a relevant analysis of this expansionist trend is done by Correcher Mira 2021.
} 
concept is indented to protect specific social groups who had traditionally suffered from structural behaviors of oppression and discrimination ${ }^{33}$, by affirming that "the phobic discourse also has other aspects, being one of them, undoubtably, the one that foster the rejection and the exclusion from political life, and physical elimination, of the people that do not share the ideology of the intolerant". ${ }^{34}$ The link between the portrait burning and the power this act has to exclude the King from the political sphere or even to provoke his assassination is not proportionally justified by assuming that it, per se, is hate speech. As affirmed by the ECtHR, not every statement that might be considered as hate speech has enough power to curtail the right to freedom of expression.

2. Secondly, the reinforced protection of the Crown as a symbol of the Spanish unity. The SCC affirms that the dismissal of the amparo is based on the hateful character that has the fact of setting on fire the King's portrait. It also declares that our legal system does not have any limitation to defend republican or antimonarchical ideas. Nevertheless, the SSC assumes that this burning was done in order to "foster a feeling of scorn or even hate to the Royal Family, and the institution they represent". ${ }^{35}$ This is a clear contradiction in the arguments used by the SCC to limit the right to freedom of expression of Stern Taulats and Roura Capellera, as it means to recognize, de facto, a special protection of the honor of the Royal Family. It is impossible combine the protection a wide-open public debate about social relevant issues, and establishing a special protection system for state representatives. Moreover, according to the ECtHR this is contrary to the ECHR protection of the right to freedom of expression as previously analyzed. The legal system should not protect public representatives from the criticism of the citizens. We might agree that burning down a portrait, or a flag, is an extreme and harsh way of expressing an idea or feeling. However, in this case it was just the expression of antimonarchical ideas at the end of a rally against the Spanish monarchy (Presno Linera 2018, p. 545). The King is not singled as individual, but as the Head of a monarchical State.

3. Prison sentence. The fact that the prison sentence was transformed into a fine cannot fade away the unproportionate response that the PC imposes to these behaviors. As previously said, the ECtHR affirms that when evaluating a case where the rights in conflict are the freedom of expression and the reputation or honor of public representatives (and in general hate speech cases), prison sentences must be reserved for exceptional situations. In this case, the SCC justifies it by assessing that the burning was done by two people

\footnotetext{
${ }^{33}$ According to the article 510 PC the categories that are protected from hateful, hostile, discriminatory or violent messages are ethnicity, race or nationality, national origin, sex, sexual orientation or identity, illness or disability. Bilbao Ubillos 2018, pp. 8-11 and 27-28.

${ }^{34}$ SCC judgement $177 / 2015$, from July $22^{\text {nd }}, 2015$, para. 4 . Author's translation. Original text: "Pero lo cierto es que el discurso fóbico ofrece también otras vertientes, siendo una de ellas, indudablemente, la que persigue fomentar el rechazo y la exclusión de la vida política, y aun la eliminación física, de quien no comparten el ideario de los intolerantes". This will be pointed out by the NGO Article 19 in their participation in the case before the ECtHR. See: ECtHR judgment Stern Taurlas et Roura Capellera c. Espagne, 16 june 2018, para. 28.

${ }^{35}$ SCC judgement 177/2015, from July 22 ${ }^{\text {nd }}$, 2015, para. 5. Author's translation. Original text: "[Le hecho de la quema de las fotografías se realiza con el objetivo de] avivar el sentimiento de desprecio o incluso de odio hacia los Reyes y la institución que representan".
} 
wearing baklavas, so it is a "circumstance that helps the execution of the crime and the impunity of their authors". ${ }^{36}$ The SCC fails to establish an adequate balance between the following facts: on one hand, Roura and Stern burned indeed the portrait and were wearing baklavas, but also that it was done in front of the media that were recording the whole incident; and on the other hand, they participated in the previous demonstration, so that their identification was an easy task to do by the police.

It is expected from the judges of every supreme or constitutional court, a reflexive and well substantiated application of the legal system, where the superior values and fundamental rights are proportionately evaluated and applied to the specific circumstances under judgment. However, in this case, the SCC made an irreflexive and pure positivistic application of the PC, without constructing a solid constitutional argumentation to defend the dismissal of the appeal.

\subsection{The case before the ECtHR.}

As expected, this case arrived before the ECtRH $\cdot{ }^{37}$ Following the pattern described before, the Court firstly evaluated if the interference on the right to freedom of expression was necessary in a democratic society. The ECtRH recalls its well-establish ${ }^{38}$ case law where the right to freedom of expression is protected not only in cases where the information or ideas that are well received by the society, but also in cases that may shock or disturb it. When it comes to a speech related to the area of public debate, the ECtRH remembers that the margin of appreciation States have is quite limited, as it is basic for the protection of the debate of public interest questions.

Recalling the decision Otegi Mondragón v. Spain, the ECtRH confirms that the right of freedom of expression is not unlimited. The restrictions that might be applied to it are linked with the incitement to the use of violence or speeches that qualify as hate speech. The ECtHR confirms that the facts being under evaluation did not amount neither of them following these arguments. Firstly, when doing a holistic evaluation of the conduct performed by Stern Taulats and Roura Capellera, the burning must be considered as a symbolic expression of dissatisfaction, instead of an open call to perform acts of violence against the King. ${ }^{39}$ Although extreme, it was not followed by the commission of other crimes against the Head-of-Sate, and the debate about monarchy or republicanism is a matter of public interest, even though if presented in a way that shocks. This is required by the spirt if pluralism, tolerance and openness required by every democratic society.

\footnotetext{
${ }^{36}$ SCC judgment $177 / 2015$, from July $22^{\text {nd }}, 2015$, para. 5. Author's translation. Original text: “[ejecutar el hecho mediante disfraz] es una circunstancia que favorece la ejecución del delito y la impunidad de sus autores".

${ }^{37}$ This judgment is just available in French on its original version. ECtHR judgment Stern Taurlas et Roura Capellera c. Espagne, 16 june 2018.

${ }^{38}$ The ECtHR has a vast caselaw regarding the interpretation of freedom of expression and public debate. See in a non-exhaustive way the ECtHR judgments: Colombani and others v. France, 25 September 2002; Féret c. Belgique, 10 December 2009.

${ }^{39}$ ECtHR judgment Stern Taulats and Roura Capellera v. Spain, paras. 39-40. Presno Linera 2018, pp. 546-548.
} 
Secondly, the facts could not be evaluated as hate speech because they were not directed towards the social groups traditionally identified not only by the ECtHR, but also by the definition of hate speech issued by international actors such as the Council of Europe. It is important to underline that the SCC, even if quoting caselaw from the ECtHR, mislead its content because as pointed before, the SCC made an expansive interpretation of this concept that is not considered neither in the international arena, nor by the Spanish PC. Lastly, the ECtHR has well-recognized that granting a special protection before criticism to state representatives is against the spirit of the article 10 ECHR.

\subsection{An expected result}

As pointed out by Habermas, public sphere is the place where debates get amplified, reaching more people, and making a connection between private and public life (Habermas 2010, pp. 454-460). To burn a portrait of the King might be seen as an extreme way to present the debate about republicanism or a monarchy, that has been present in the Spanish society for ages. Despite this, we might conclude that the decision adopted by the Spanish Courts had as only purpose to establish a special system of protection of the leading figure of the King, privileging its protection above the right of freedom of expression (Belda 2019, pp. 60-61). This is not in line with the caselaw of the ECtHR, and because of that, this court decided that there was a violation of the article 10 ECHR. All in all, if we analyze all the proceeding of this case, the position adopted by the Spanish courts is unjustifiable.

The outcome of this judgment was quite expectable, as the decision adopted at the national level directly contradicted the well-establish caselaw of the ECtHR about this mater (Corral Maraver 2020, pp. 17-19), repeating almost the same problems pointed out by the ECtHR in the Otegi Mondragon case ${ }^{40}$ (Presno Linera 2018, pp. 548-549).

\section{SCC CASE 190/2020 (FLAG SCORNING CASE).}

This case is followed by the article $543 \mathrm{PC}$, as the behavior under evaluation is the scorning of the Spanish flag done by a union representative in a military compound. Although the previous cases evaluate the application of the article 490 PC, the animus of

\footnotetext{
${ }^{40}$ It is important to underline that, by the time this SCC judgement was issued the "Brussels Declaration on Enhancing the National Implementation of the System of the European Convention on Human Rights, our shared responsibility" was already signed (March 26th-27th, 2015). In this document State Parties agree on ensuring the application and effective implementation of the ECHR by "Bearing in mind the jurisdiction of the Court to interpret and apply the Convention, the Conference underlines the importance of clear and consistent case-law as well as the Court's interactions with the national authorities and the Committee of Ministers, and in this regard: welcomes the Court's dialogue with the highest national courts and the settingup of a network facilitating information exchange on its judgments and decisions with national courts, and invites the Court to deepen this dialogue further". More steps are detailed on this action plan that has as objective to coordinate the responses between the ECtHR and the Highest National Courts. See COE 2019, pp. 10-15. However, Spain has not ratified the Protocol No. 16 to the ECHR, that will allow the SCC (or the $\mathrm{SC}$ ) to request to the ECtHR to give advisory opinions on questions of principle relating to the interpretation or application of the rights defined in the ECHR or the protocols thereto.
} 
both articles pursue similar objectives, that is the protection of an alleged legal asset ${ }^{41}$ that represents the unity of the Spanish nation (on the previous sections the Royal family, now the Spanish flag). ${ }^{42}$ Thus, it is relevant to study them jointly so we can evaluate if the SCC implements the standards set by the ECtHR about the limitation of the right to freedom of expression developed on its caselaw, and especially, the standards set out in the two above mentioned cases against Spain.

The proven facts of the case read like this. There was an open labor conflict between the cleaning services (outsourced) of the military compound of El Ferrol and their company. Workers had been demonstrating themselves regularly during the daily ceremony of the rising of the flag yelling sentences like "the flag does not pay our bills". ${ }^{43}$ However, on October $30^{\text {th }}, 2014$, a representative of the worker's union yelled "here you have the silence of the fucking [puta] flag" and "we have to set that fucking [puta] flag on fire". ${ }^{44}$

The SCC granted the amparo procedure recalling the ideas developed in sections 2 and 3, as it affirms that according to the ECtHR caselaw State symbols cannot have a privileged procedure of protection, especially in cases linked with flags and politician portraits burnings. ${ }^{45}$ However, this is only an instrumental assertion made by the SCC, as the substantial application of the caselaw of the ECtHR cannot be found in the decision ${ }^{46}$. The rationale of the judgement is expressed as follow.

Firstly, the SCC confirms that the regulation established by the article $543 \mathrm{PC}$ pursues a legitimate aim, that is not indeterminate as it is an accessible and foreseeable.

\footnotetext{
${ }^{41}$ There is an important section of the legal doctrine that argues that the article 493 PC do not identify any legal assets worth to be protected. In favor of this opinion: Santana Vega 2009, pp. 49-54; Llabrés Fuster 2015 b p. 381; Tamarit Sumalla, 2016, pp 1755-1758. Against this opinion: Benlloch Petit 2001, pp. 182185. As we will defend, we support the first group of scholars, as it is tremendously difficult to identify any legal asset with enough entity to justify the limitation of the fundamental right to freedom of expression. Supporting the position of Portilla Contreras (1991, pp. 30-31), when we are before a problem like this, the principle of minimum criminal intervention requires to reduce the impact the penal code has on fundamental rights.

${ }^{42}$ It is highly problematic to protect objects that represent the Spanish unity through the PC. Moreover, we have to have in mind that the colors Spanish flag did no change from the Francoism area to the constitutional times (only the coat of arms). Thus, some part of the population might feel completely unconnected with it. Vernet i Llobet 2003, pp. 120-122.

${ }^{43}$ SCC judgment 190/2020, from December 15 ${ }^{\text {th }}, 2020$, p. 2. Author's translation. Original text, in Galician reads as: "a Bandeira non paga as facturas".

${ }^{44}$ SCC judgment 190/2020, from December $15^{\text {th }}, 2020$, p. 2. Author's translation. Original text, in Galician reads as: "aquí tedes o silencio da puta bandeira" and "hai que prenderlle lume a puta bandeira". To this extend, Llabrés Fuster considers that statements like "Spanish flag no, Ikurriña [flag of the Basque country] yes" or "out, out, out the Spanish flag" should not be considered as behaviors with criminal relevance. Llabrés Fuster 2015b, p. 391.

${ }^{45}$ SCC judgment 190/2020, from December $15^{\text {th }}, 2020$, p. 9.

${ }^{46}$ It would be quite relevant for Spain to ratify the Protocol No. 16 to the ECHR to allow the SCC to ask for advisory opinions to the ECtHR instead of making misleading interpretations of their caselaw, that might result in new judgements against Spain.
} 
The Court affirms "it is beyond any reasonable doubt the relevance and legitimacy of this article, because it protects the symbols of the constitutional state, including the flag, the only symbol specifically constitutionalized". ${ }^{47}$ Unfortunately, this reasoning has several flaws. On one hand, the SCC does not identify any superior legal valued to be protected $^{48}$, to justify the protection of national symbols over a fundamental right like freedom of expression. ${ }^{49}$ The flag might be a symbol particularly mentioned in the Spanish constitution, but so it is the fundamental right to freedom of expression, also protected in international treaties. On the other hand, the protection of national symbols is not among the legitimate aims covered by the ECHR ${ }^{50}$. In fact, it is excluded as we can argue, mutatis mutandis, observing the judgements analyzed in sections 2 and 3. It is highly troublesome to protect the especial representative and integrative significance ${ }^{51}$ that political symbols have (if so) through the PC, as they are an essential part of the political debates that take place when discussing relevant social matters.

Secondly, the SCC recalls its vast caselaw where it establishes that the freedom of expression is one of the columns of a free and democratic society. The court did so altogether with ECtHR caselaw that recognizes that this right protects a wide-range set of expressions, from the ones that are well-received by the society, to those that offend, shock or disturb the State or any sector of the population. This is so because it is required by pluralism, tolerance and broadmindedness without which there is no democratic society. ${ }^{52}$ Moreover, the SCC also recalls some of the boundaries that this right has, like the exclusion of the an "alleged right to offend" 53 , hate speech, or affray and looting, in order to protect the equal dignity of all human beings. Beyond these limitations, an extensive granting of the right to freedom of expression must be protected to prevent any chilling effect (Colomer Bea 2019, pp. 112-113). It is striking that the SCC brings to this case the protection of the human dignity, when it refers to the Spanish flag. Moreover, the

\footnotetext{
${ }^{47}$ SCC judgment 190/2020, from December 15 th, 2020 , p. 9. Author's translation, original text: "Ninguna duda razonada cabe sobre la relevancia y legitimidad de la finalidad del tipo penal, pues se dirige a proteger los símbolos y emblemas del Estado constitucional, entre los que se encuentran las banderas, únicos símbolos expresamente constitucionalizados". For exhaustive research about the symbols being constitutionalized in Spain see: Belda, 2019, pp.48-56.

${ }^{48}$ The identification of the legal superior value that this article protects has been discussed by the legal doctrine. Some identify a sort of national honor, while others the protection of public peace. Despite this, an important number of commentators stand for its elimination from the PC. Rebollo Vargas 2014, pp. 100110.

${ }^{49}$ The signification of objects like flags have, rely on the symbolic reference they might have for people. For some they would be a great symbol of unity and freedom, whether for others it would represent nothing, or an oppressive system. Rebollo Vargas 2014, pp. 84-85.

${ }^{50}$ Article 10 of the ECHR protects as legitimate aims: national security, territorial integrity or public safety, for the prevention of disorder or crime, for the protection of health or morals, for the protection of the reputation or rights of others, for preventing the disclosure of information received in confidence, or for maintaining the authority and impartiality of the judiciary.

${ }^{51}$ SCC judgment 94/195, from July 29", argument 7: “Al símbolo político corresponde, pues, al lado de una función significativa integradora, una esencial función representativa e identificadora”.

${ }^{52}$ ECtHR judgment Handyside v. the United Kingdom. December $7^{\text {th }}$, para. 49

${ }^{53}$ This limitation is well developed by the SCC caselaw: SCC judgment 6/2000, January $17^{\text {th }}$; SCC judgment $148 / 2001$, October $15^{\text {th }}$, SCC judgment $177 / 2015$, July $22^{\text {nd }}$, among many others.
} 
other references to hate speech, affray and looting, as ways of curtailing the freedom of expression are equally unconnected to this case, as the statements against the flag done by the union representative do not fit any definition of hate speech, and did not provoke any alteration of the public peace.

Finally, the amparo was set aside after the specific evaluation of these circumstances:

1. The statements were done in the "most solemn ceremony" 54 that takes place in a military compound.

2. The use of words like fuck (puta) to refer to the Spanish flag, and the willing to get it on fire.

3. The unnecessary use of the foreword expressions and their lack of connection to defend the labor rights of the cleaning staff.

4. And, the intense feeling of humiliation suffered by the military personnel present in the ceremony, and some other demonstrators that expressed their immediate disagreement with the statements.

Once all four factors were analyzed, the SCC is convinced that the statements go beyond the protected contents of the right to freedom of expression. The use of derogatory words towards a symbol of the Spanish unity, and the willingness to set it on fire is intended as a direct attack to the principles and the values it represents. Moreover, the SCC makes an extra effort to separate this case from the ones analyzed in sections 2 and 3 . The court affirms that in this case the behavior is not directed against a politician or a representative of the state, but it consists in some statements performed in a pacific demonstration done in front of a military compound against the Spanish flag, completely unnecessary and unconnected with the labor claims expressed by the cleaning staff. Thus, the SCC concluded that the assertions are "objectively offensive" $"$, so the amparo is dismissed.

The rationale used by the SCC to justify its decision neither do a correct evaluation of the case circumstances nor the ECtHR caselaw. Firstly, as pointed out in some of the dissenting opinions, the statements under evaluation can barely being observed as unconnected to the labor claims, as they were done while the daily demonstration of the workers and the union representatives was taking place. The choosing of the flag raise ceremony, the use of words like fuck (puta), and desire of setting it on fire, might be socking or disturbing for the military staff and some of the demonstrators, but they were done with the intention to blow the whistle on the passivity of the military representatives that did nothing to mediate between the workers and the externalized cleaning company.

Moreover, the arguments used by the SCC to make a clear separation between the behaviors analyzed in sections 2 and 3, and the current one is outlandish and mislead. One of the core standards set by the ECtHR in Otegi Mondragón v. Spain and Stern Taulats and Roura Capellera v. Spain is the prohibition to establish a privileged protection of the symbols of the state before the right to freedom of expression. The SCC limits this

${ }^{54}$ SCC judgment 190/2020, from December 15 th, 2020 , p. 20.
${ }^{55}$ SCC judgment 190/2020, from December $15^{\text {th }}, 2020$, p. 23. 
standard to politicians or state representatives, but this is not what the ECtHR recognizes. The concept of national symbols must encompass anything that represents the state itself, not only the flag, the coat of arms, or the national anthem, but also the Head-of-State or any other member of the Royal Family (Belda 2019, pp. 56-74). It is irrelevant that the PC punishes in different articles (490 PC and 543 PC) behaviors that can be gather together under acts against symbols that represent Spain. If we analyze their animus, both procure prerogatives to concrete symbols of the Spanish nation, a circumstance that is excluded from the interpretation the ECtHR does of the article $10 \mathrm{ECHR}$.

Finally, it is important to highlight that the SCC mentions the doctrinal debate around the article $543 \mathrm{PC}^{56}$, but prefers not to take it into account because "judges are only bound by the principle of legality, being the article $543 \mathrm{PC}$ a norm in force, the only legal answer for this case is the foreseen by the penal code". ${ }^{57}$ This statement of the SCC is troublesome, as it does not justify why the SCC decided to promote the principle of legality before the principle of democratic rule of law. Traditionally, the principle of criminal legality has been formulated as "Nullum crimen, nulla poena sine previa lege penale, [...] absolute legal reservation for crime definitions and its consequences; the proscription of customary law as a source of criminal law; the prohibition of the analogy in mala partem and its extensive interpretation; non-retroactivity of the un-favorable criminal regulations; legal certainty; prohibition of bis in idem; jurisdictional protections and criminal execution protections" (Arroyo Zapatero 1983, p.10). ${ }^{58}$ As we can see, this principle is only shaped by positive law. However, Spain is configured as a social and democratic rule of law state (Díaz 2010, pp. 46-57, and pp. 179-180), which implies, among others, the formal jurisdictional protection of fundamental rights and freedoms and its substantial realization (Díaz 2010, p. 46 and pp. 54-57). On its reasoning, the SCC does not explain why it is better to implement the requirements of the principle of legality instead of combining it with the social and democratic rule of law principles. By doing this, not only the SCC would have brought into the discussion more superior values and principles that had a key role in this case, like the principle of justice, but also it would have recognized the importance doctrinal debates have for the good health of a legal system..$^{59}$

\footnotetext{
${ }^{56}$ Llabrés Fuster (2015b, p. 381) affirms that the majority of the doctrine sustains founded doubts about constitutionality of this article. A reminiscence of a Criminal law based on political grounds that in the protection of democratic values.

${ }^{57}$ SCC judgment 190/2020, from December 15 th 2020 , p. 3. Author's translation. Original text: "Los jueces y tribunales españoles están sujetos únicamente al principio de legalidad, y tratándose el artículo 543 del CP de una norma en vigor, la única respuesta que merece el caso es la penal legalmente prevista".

${ }^{58}$ Author's translation. Original text: "Nullim crime, nulla poena sine previa lege penale,[...], reserva absoluta de ley para la definición de las conductas constitutivas de delito y de las correspondientes penas; la proscripción de la costumbre como fuente de Derecho penal; la prohibición de la analogía in mala partem y de la interpretación extensiva; la irretroactividad de las normas penales desfavorables para el reo; la determinación, certeza o taxatividad de las normas penales; la prohibición del bis in ídem; la garantía jurisdiccional y la garantía de la ejecución penal".

${ }^{59}$ It is interesting the opinion of Portilla Contreras $(2005$, p. 7) regarding the lack of justice and ethics in the current configuration of the criminal subsystem.
} 
The combination of these two principles compels the SCC to evaluate if the article 543 PC curtails the fundamental right to freedom of expression, and if so, make it unconstitutional (Laporta 1994, pp. 140-143), or to develop an interpretation of this article that truly protects this right in before criminal behaviors that do not have an identifiable legal asset. Fundamental rights are limits to the activity of the legislators. Thus, "for a norm to be valid and enforceable it is not enough that it is passed according to the corresponding procedure, but also it is needed that its substantial contents respect the principles and the rights protected in the constitution" (Ferrajoli 2010, p. 66). By presupposing that the formal validity of the article 543 PC encompasses the substantial one, the SCC is overlooking the reality that a legal system might have norms that are valid, so that in force, but they might be unconstitutional because of paradigm that constitutions brought to the evaluation of the validity of the norms. Therefore, the SCC should have done a full examination of the contents of the article $543 \mathrm{PC}$ to evaluate if it unconstitutionally limits the fundamental right to freedom of expression.

This decision of the SCC makes possible to advance a new case against Spain before the ECtHR. ${ }^{60}$ It is unjustifiable the obstinacy showed by the Spanish courts to restrict the right to freedom of expression in cases that are clearly related to the defense of maters of public interest. ${ }^{61}$ Scorning a flag is not a behavior that should have any relevance from the criminal perspective, as it does not affect any superior value of the legal system that makes proportional to curtail a fundamental right. This has been repeatedly said by the ECtHR, and constantly ignored by the Spanish courts (Martín Herrera 2018, pp. 61-64).

\section{SOME CONCLUSIONS}

The SCC has lost several opportunities to truthfully stand in favor of the protection of the right to freedom of expression in cases related to national symbols or state representatives, in line with the ECtHR standards. In the national judgements analyzed in this text, the SC and SCC seem to be using the ECtHR caselaw as a pure formal protection against future decisions against Spain. This is so because, even though these courts quote ECtHR judgments, they use it adopt decisions that are diametrically opposed to the ratio decidendi of the ECtHR. An important step forward to avoid this situation would be the ratification of the Protocol No. 16 to the ECHR. Moreover, it is fundamental to draw the attention and to make an in-depth critical reflection about the major problems pinpointed in the previous sections:

Firstly, the State does not need to protect itself from the its citizens. Social criticism towards politicians, State representatives, or national symbols can be represented in many ways, from demonstrations, to flag or portrait burnings, or by whistling the national

\footnotetext{
${ }^{60}$ In line with the opinion expressed by Martín Herrera (2018, pp. 71-76), once the ECtHR issued its Stern Taulats and Capellera Roura judgment.

${ }^{61}$ These cases are not only related to national symbols and state representatives. There has been an important increase in the cases that curtail the right to freedom of expression concerning the glorification of terrorism like the cases of Titiriteros, Hasel, Strawberry and Valtonyc (singers), or Cassandra (Twitter user). Correcher Mira 2019, pp. 322-339; Surribas Balduque 2020, pp. 411-428.
} 
anthem. All of them, even if shocking or disturbing for some people, are ways to express feelings or ideas that must be protected by the right to freedom of expression in every democratic rule of law state. In the first two cases, Spain has been declared as violating article 10 ECHR by ECtHR, and if the last case is heard before this court, a new declaration of violation is highly likely to be issued. The protection of national symbols and state representatives as it has been done so far, is an attempt to abstract and criminalize that part of the public debate. Thus, it is an abusive restriction on a fundamental right, incompatible with the ECHR, but as well with the spirit of the Spanish constitution.

Secondly, it does not exist such a thing called objectively offensive statements. To offend someone implies to evaluate a human feeling, an area abstracted from objectivity. Some people might be offended because of a flag burning, others might see it as a sign of political dissent. The same might happen with the offenses to the Crown, or when the national anthem is whistled. To stablish that these acts are objectively offensive statements, might prevent national courts from performing the evaluation that is required when analyzing cases that might curtail a fundamental right. Freedom of expression must know a very few limitations, in particular in the political debate. Beyond this area, the incitement to commit crimes and extreme hate speech are among the limitations that impose a restriction on this basic right. Hate speech has been defined by Council of Europe ${ }^{62}$ as "covering all forms of expression which spread, incite, promote or justify racial hatred, xenophobia, anti-Semitism or other forms of hatred based on intolerance, including: intolerance expressed by aggressive nationalism and ethnocentrism, discrimination and hostility against minorities, migrants and people of immigrant origin". ${ }^{63}$ The SCC cannot create a new definition to fit in new behaviors that are not directed towards the protected groups, to force in the protection of symbols and state representatives. Statements, when directed to state officials or politicians, even if harsh or highly offensive, cannot foster, protect and reproduce a system of oppression based on intolerance that promotes the limitation of fundamental rights of certain people because of their origin, nationality, sexual orientation, ethnicity, among others.

Lastly, the SCC should do a deep critical reflection about its role as supreme interpreter of the Spanish constitution. Doctrinal debates, like the one around articles 490PC and 543PC, are important indicators that make visible possible distortions between the constitution and lower laws. Referring to a liberal conception of the rule of law and the legality principle to disregard this reality means to give up on the constitutional duties the SCC has, especially in slippery slope subjects that might have a chilling effect on a fundamental right.

\footnotetext{
${ }^{62}$ Not only the Council of Europe has a definition. Other actors, such as the UN, also have one. It defines hate speech as "any kind of communication in speech, writing or behavior, that attacks or uses pejorative or discriminatory language with reference to a person or a group on the basis of who they are, in other words, based on their religion, ethnicity, nationality, race, color, descent, gender or other identity factor". UN, Strategy and Plan of Action on Hate Speech, 2019. Retrieved at: https://www.un.org/en/genocideprevention/ documents/advising-and-mobilizing/Action_plan_on_hate_speech_ES.pdf

${ }^{63}$ Council of Europe Recommendation No. R (97) 20, 30 October $1997 .{ }^{*}$ University of Valencia, Human Rights Institute, Andres.gascon@uv.es
} 


\section{REFERENCES}

Arroyo Zapatero, L., (1983). Principio de legalidad y reserva de ley en materia penal. Revista Española de Derecho Constitucional. 3-8, 9-46.

Belda, E., (2019). Elementos simbólicos de la Constitución Española. La protección del uso de los símbolos por las personas y las instituciones. Revista Española de Derechos Constitucional. 117, 45-75. https://doi.org/10.18042/cepc/redc.117.02

Benlloch Petit, G. (2001). El Derecho penal ante el conflicto. Reflexiones entrono a la relevancia penal de determinados fines, opiniones o motivos políticios o ideológicos y su legitimidad. $A D C P C$. LIV, 175-227.

Bilbao Ubillos, J. M., (2018). La STEDH de 13 de marzo de 2018 en el asunto Stern Taulats y Roura Capellera contra España: la crónica de una condena anunciada. Revista General de Derecho Constitucional 8, 1-29.

Bilbao Ubillos, J. M. (2021, June 8) La protección penal de los símbolos nacionales y la libertad de expresión [Video]. Canal UNED. https://canal.uned.es/ video/60c87bbeb60923203a66c302

COE, (2019). Enhancing the national implementation of the system of the European Convention on Human Rights. Strasbourg: COE. https://edoc.coe.int/en/europeanconvention-on-human-rights/8230-enhancing-the-national-implementation-ofthe-system-of-the-european-convention-on-human-rights.html

Colomer Bea, D., (2019). La doctrina del efecto desaliento como punto de conexión entre el Derecho penal y los derechos fundamentales. Cuadernos Electrónicos de Filosofía del Derecho. 41, 97-116. https://doi.org/10.7203/CEFD.41.13969

Corral Maraver, N., (2020). Sentencia del TEDH en el asunto Stern Taulats y Roura Capellera c. España. Reflexiones sobre el delito de injurias a la corona y el derecho a la libertad de expresión política en España. Revista General de Derecho Penal. 34, 1-21.

Correcher Mira, J. (2019). Limites penales a la libertad de expresión: sobre el enaltecimiento del terrorismo en redes sociales. Cuadernos Electrónicos de Filosofía del Derecho. 39, 322-339.

Correcher Mira, J. (2021). La banalización del ciscurso del odio: una explosión de los colectivos ¿vulnerables?. Indret 2, 86-149. https://doi.org/10.31009/InDret.2021.i2.04

Cuerda Arnau, M. L., (2007). Proporcionalidad penal y libertad de expresión: la función dogmática del efecto desaliento. RGDP. 8, 1-43.

Díaz, E. (2010). Estado de Derecho y sociedad democrática. Madrid: Taurus.

Ferrajoli, L., (2010). Derechos y garantías. La ley del más débil. Madrid: Trotta.

Gascón Cuenca, A., (2016). El discurso del odio en el ordenamiento jurídico español: su adecuación a los estándares internacionales de protección. Cizur Menor: Thomson Reuters Aranzadi. 
Gimbernat Ordeig, E., (2007). Los privilegios penales de la familia real. Diario de Derecho. Available from: https://www.iustel.com//diario_del_derecho/noticia. asp?ref_iustel $=1024306 \&$

Gómez Corona, E. (2011). El prestigio de las instituciones como límite a la libertad de expresión de los ciudadanos: el caso Otegi Mondragón c. España. Revista Española de Derecho Administrativo. 151, 727-741.

Habermas, J., (2010). Facticidad y validez. Madrid: Trotta.

Laporta, Francisco J., (1994). Imperio de la ley. Reflexiones sobre un punto de partida de Elías Díaz. DOXA. 15-16, 133-145.

Laurenzo Copello, P., (2019). La manipulación de los delitos de odio, in G. Portilla Contreras et al. dirs. Un juez para la democracia. Libro homenaje a Perfecto Andrés Ibáñez. Madrid: Dykinson, pp. 453-468.

Llabrés Fuster, A., (2015a). Artículo 490, in M. Gómez Tomillo et al dirs. Comentarios prácticos al Código penal. Tomo VI. Cizur Menor: Thomson Reuters-Aranzadi, pp. 95-96.

Llabrés Fuster, A. (2015b). Artículo 543, in M. Gómez Tomillo et al dirs. Comentarios prácticos al Código penal. Tomo VI. Cizur Menor: Thomson Reuters-Aranzadi, pp. 381-397.

Martín Herrera, D., (2018). ¿Serán precisas más condenas del TEDH para dejar de proteger lo (in)defendible en España? Crónica de una interminable manipulación del hate speech para enmudecer al disidente molesto. Revista Chilena de Derecho y Ciencia Política. 9-1, 40-79. https://doi.org/10.7770/rchdcp-V9N1-art1473

Portilla Contreras, G., (1991). Principio de intervención mínima y bienes jurídicos colectivos. Derecho Penal y Criminología. 13-43, 19-44.

Portilla Contreras, G., (2005). Los excesos del formalismo jurídico neofuncionalista en el normativismo del derecho penal. RGDP. 4, 1-27.

Presno Linera, M. Á., (2018). Crónica de una condena anunciada: el asunto Stern y Roura Capellera c. España sobre la quema de fotos del rey. UNED. Teoría y Realidad Constitucional. 42, 539-549. https://doi.org/10.5944/trc.42.2018.23644

Ramos, F., (2007). El secuestro del Jueves y las injurias periodísticas a la corona, un injustificable ataque a la libertad de expresión. Ámbitos. 16, 151-186.

Rebollo Vargas, R., (2014). Bases para una interpretación crítica del delito de ultrajes a España. Estudios Penales y Criminológico., XXXIV, 81-126.

Rodríguez Montañés, T., (2013). Otegi Mondragón c. España (STEDH de 15 de marzo de 2011): el derecho a la libertad de expresión en el ámbito del discurso político extremo, in R. Alcácer Guirao et. al., coords. Conflicto y diálogo con Europa. Las condenas a España del Tribunal Europeo de Derechos Humanos. Cizur Menor: Thomson Reuter-Civitas, pp. 613-640. 
Sánchez de Diego Fernández de la Riva, M., (2011). Las injurias al Rey a la luz de la jurisprudencia del TEDH. Sentencia del TEDH. Otegi Mondragón contra España (Requête $\mathrm{N}^{\mathrm{o}}$ 2034/07), 15 de marzo 2011. RGDE. 24, 1-21.

Santana Vega, D. M., (2009). El delito de ultrajes a España y a sus Comunidades Autónomas: ¿Protege algún bien jurídico-penal?.Cuadernos de Política Criminal 99, 35-66.

Serrano Maíllo, I., (2011). El derecho a la libertad de expresión en la jurisprudencia del Tribunal Europeo de Derechos Humanos: dos casos españoles. UNED. Realidad y Teoría Constitucional. 28, 575-591.

Soto García, M., (2012). TEDH - Sentencia de 15.03.2011, Otegi Mondragón c. España, 2034/07 - «artículo 10 del CEDH- Libertad de expresión - límites - delitos de injurias contra el Jefe del Estado - Exhortación a la violencia y discurso del odio». Los límites de la libertad de expresión en el debate político. Revista de Derecho Comunitario Europeo. 42, 78-591.

Surribas Balduque, M. (2020). La ficción como amparo legal del arte: titiriteros, raperos y libertad de expresión en la España pos 15M. Journal of Spanish Cultural Studies. 21-3, 411-428. https://doi.org/10.1080/14636204.2020.1801300

Tamarit Sumalla, J. M., (2016). Artículo 543, in G. Quintero Olivares dir. Comentarios al Código penal español. Cizur Menor: Thomson Reuters-Aranzadi, 1755-1758.

Vernet i Llobet, J., (2003). Símbolos y fiestas nacionales en España. UNED Teoría y Realidad. 12-13, 99-122.

Received: June $7^{\text {th }} 2021$

Accepted: September $9^{\text {th }} 2021$ 